\title{
Erratum to: Analysis of DNA repeats in bacterial plasmids reveals the potential for recurrent instability events
}

\author{
Pedro H. Oliveira • Kristala Jones Prather •
}

Duarte M. F. Prazeres • Gabriel A. Monteiro

Published online: 7 July 2010

(C) Springer-Verlag 2010

\section{Erratum to: Appl Microbiol Biotechnol}

\section{DOI 10.1007/s00253-010-2671-7}

The article unfortunately contained a mistake.

The legend to Fig. 2 (left-hand side column) was incomplete: "TR were predominantly found (b)." should read "TR were predominantly found within the SV40 EEP (b)."

The online version of the original article can be found at http://dx.doi. org/10.1007/s00253-010-2671-7.

P. H. Oliveira $(\square) \cdot$ D. M. F. Prazeres $\cdot$ G. A. Monteiro IBB - Institute for Biotechnology and Bioengineering,

Centre for Biological and Chemical Engineering,

Instituto Superior Técnico,

Av. Rovisco Pais,

1049-001 Lisbon, Portugal

e-mail: pcoliveira@ist.utl.pt

\section{K. J. Prather}

Department of Chemical Engineering,

Massachusetts Institute of Technology,

Room 66-458,

Cambridge, MA 02139, USA 